\title{
RESPON ORANG TUA TERHADAP PEMBELAJARAN DARING PADA MASA PANDEMI COVID-19
}

\author{
Lia Nur Atiqoh Bela Dina \\ Universitas Islam Malang \\ e-mail: lia.nur@unisma.ac.id
}

Diterima: 1 Juli 2020

I Direvisi: 7 Juli 2020

I Disetujui: 8 Juli 2020

(C)2020 Pendidikan Guru Raudhatul Atfhal Fakultas Agama Islam Universitas Islam Malang

\begin{abstract}
This research was conducted with the aim to find out the response of parents to online learning during pandemic Covid-19 that was recently implemented at KB-RA Mambaul Ulum. This research uses descriptive quantitative research. Data collection using a questionnaire instrument, with a total sample of 58 parents. Based on a questionnaire that has been distributed to parents, an average percentage of $74.8 \%$ is obtained. This shows that students' parents responded positively to online learning during pandemic Covid-19.
\end{abstract}

Kata Kunci: Parent Response, Daring Learning, Pandemic Covid-19.

\section{A. Pendahuluan}

Negara-negara di dunia saat ini tengah dihadapkan pada pandemi Covid-19, termasuk Indonesia. Pandemi Covid-19 menjadi krisis besar manusia, manusia dipaksa berhenti dari rutinitas kehidupannya sehari-hari dan diminta berdiam diri di rumah. Persebaran virus corona di berbagai negara membuat perubahanperubahan besar, seperti bidang ekonomi, teknologi dan tidak terkecuali pada bidang pendidikan.

Pandemi Covid-19 memaksa kebijakan social distancing. Kita tidak boleh berkerumun dengan orng banyak dan bahkan kita harus menjaga jarah fisik (phyisical distancing) untuk mencegah persebaran Covid-19. Pemerintah pusat hingga daerah mengeluarkan kebijakan untuk meliburkan seluruh lembaga pendidikan. Kebijakan lockdown atau karantina dilakukan sebagai upaya untuk mengurangi interaksi dengan banyak orang yang dapat memberi akses penyebaran virus tersebut.

Kebijakan belajar dari rumah mengakibatkan pembelajaran harus dilaksanakan secara daring. Mereka tidak bisa bertatap muka langsung, karena untuk pencegahan penularan Covid-19. Istilah pembelajaran daring merupakan akronim dari "dalam jaringan". Menurut Mustofa, dkk (2019) pembelajaran daring

This work is licensed under Creative Commons Attribution Non Commercial 4.0 International License Available online on: http://riset.unisma.ac.id/index.php/fai/index 
merupakan salah satu metode pembelajaran online atau dilakukan melalui jaringan internet. Pembelajaran daring dikembangkan untuk memperluas jangkauan layanan pendidikan dan juga meningkatkan ketersediaan layanan pendidikan. Meski terlihat menyenangkan, ternyata pembelajaran daring yang dilaksanakan dari rumah bukanlah sesuatu yang mudah. Selama belajar dari rumah, siswa banyak mendapatkan tugas. Belum lagi, peran orang tua yang harus mengawasi proses pembelajaran anaknya selama di rumah.

Lembaga KB-RA Mambaul Ulum yang beralamatkan di Dusun Landean Desa Klotok Kecamatan Plumpang Kabupaten Tuban diwajibkan mengambil langkah belajar dari rumah melalui pembelajaran daring. Berdasarkan wawancara dengan kepala sekolah, pembelajaran daring yang dilakukan KB-RA Mambaul Ulum tentu saja mendapatkan respon yang beragam dari orang tua siswa. Sebelumnya KB-RA Mambaul Ulum tidak pernah melaksanakan pembelajaran daring, namun akibat pandemi Covid-19 mau tidak mau sekolah harus mengambil kebijakan untuk melaksankan pembelajaran daring. Kegiatan pembelajaran dari rumah dilaksanakan dengan cara penugasan, koordinasi terkait penugasan dilakukan dengan menggunakan aplikasi whatsapp antara guru dan orang tua siswa. Jadi, pembelajaran daring ini menuntut orang tua mendampingi anaknya selama belajar dari rumah. Berdasarkan uraian di atas, maka peneliti tertarik untuk mengetahui lebih jauh respon orang tua siswa KB-RA Mambaul Ulum terhadap pembelajaran daring yang baru diberlakukan.

\section{B. Metode}

Penelitian ini menggunakan metode analisis deskriptif dengan pendekatan kuantitatif. Sudjana (2001) menjelaskan bahwa "penelitian deskriptif adalah penelitian yang berusaha mendeskripsikan suatu gejala, peristiwa, kejadian yang terjadi di masa sekarang. Penelitian ini dimaksud untuk mendeskripsikan respon orang tua terhadap pembelajaran daring pada masa Covid-19.

Populasi dan Sampel penitian ini adalah Orang tua siswa KB-RA Mambaul Ulum Landean Klotok Plumpang Tuban sejumlah 58 orang. Teknik pengumpulan data yang digunakan yaitu instrumen angket, angket berisikan 10 pertanyaan dan 2 jawaban ya atau tidak. Intrumen tersebut sebelumnya telah melalui uji validitas dan reliabilitas. Adapun pertanyaan-pertanyaan yang diajukan untuk mengetahui respon orang tua terhadap pembelajaran daring pada masa pandemi Covid-19 adalah sebagai berikut. 
Tabel 1. Pernyataan Respon Orang Tua terhadap Pembelajaran Daring pada Masa Pandemi Covid-19

\begin{tabular}{cl}
\hline No & \multicolumn{1}{c}{ Pernyataan } \\
\hline $\mathbf{1}$ & $\begin{array}{l}\text { Pembelajaran daring membuat saya memiliki banyak waktu bersama } \\
\text { anak }\end{array}$ \\
$\mathbf{2}$ & Pembelajaran daring membuat saya semakin kompak dengan anak \\
$\mathbf{3}$ & $\begin{array}{l}\text { Pembelajaran daring membuat saya mengenal lebih dekat lagi sikap dan } \\
\text { karakter anak }\end{array}$ \\
$\mathbf{4}$ & Pembelajaran daring tidak membuat saya kerepotan \\
$\mathbf{5}$ & Pembelajaran daring tidak membuat saya mengeluarkan dana lebih untuk \\
& membeli kuota internet \\
$\mathbf{6}$ & Pembelajaran daring tidak menyita waktu saya \\
$\mathbf{7}$ & Pembelajaran daring tidak membuat aktivitas saya terganggu \\
$\mathbf{8}$ & Pembelajaran daring tidak membuat anak saya sulit memahami materi \\
& pelajaran \\
$\mathbf{9}$ & Pembelajaran daring tidak membuat anak saya cepat bosan \\
$\mathbf{1 0}$ & Pembelajaran daring membuat anak saya semakin semangat belajar \\
\hline
\end{tabular}

Analisa data dihitung menggunakan rumus prosentase sebagai berikut.

$$
P=\frac{F}{N} \times 100 \%
$$

Keterangan:

$\mathrm{P}=$ Prosentase yang dicari

$\mathrm{F}=$ Frekuensi

$\mathrm{N}=$ Jumlah responden

Prosentase tersebut kemudian diinterpretasikan berdasarkan kriteriakriteria interpretasi berikut.

Tabel 2. Kriteria respon orang tua

\begin{tabular}{ll}
\hline Persentase & Kategori \\
\hline $85 \% \leq \mathrm{P}$ & Sangat positif \\
\hline $70 \% \leq \mathrm{P}<85 \%$ & Positif \\
\hline $50 \% \leq \mathrm{P}<70 \%$ & Kurang positif \\
\hline $\mathrm{RS}<50 \%$ & Tidak positif \\
\hline
\end{tabular}




\section{Hasil dan Pembahasan}

Penelitian ini merupakan penelitian deskriptif untuk mendeskripsikan respon orang tua siswa KB-RA Mambaul Ulum terhadap pembelajaran daring pada masa pandemi Covid-19. Adapun hasil penelitian yang diperoleh adalah sebagai berikut.

Tabel 3. Hasil Respon Orang Tua

\begin{tabular}{|c|c|c|c|}
\hline \multirow[t]{2}{*}{ No } & \multirow[t]{2}{*}{ Pernyataan } & \multicolumn{2}{|c|}{$\begin{array}{l}\text { Prosentase } \\
\text { Jawaban }\end{array}$} \\
\hline & & Ya & Tidak \\
\hline 1 & $\begin{array}{l}\text { Pembelajaran daring membuat saya memiliki banyak } \\
\text { waktu bersama anak }\end{array}$ & $100 \%$ & $0 \%$ \\
\hline 2 & $\begin{array}{l}\text { Pembelajaran daring membuat saya semakin kompak } \\
\text { dengan anak }\end{array}$ & $98 \%$ & $2 \%$ \\
\hline 3 & $\begin{array}{l}\text { Pembelajaran daring membuat saya mengenal lebih } \\
\text { dekat lagi sikap dan karakter anak }\end{array}$ & $100 \%$ & $0 \%$ \\
\hline 4 & Pembelajaran daring tidak membuat saya kerepotan & $68 \%$ & $32 \%$ \\
\hline 5 & $\begin{array}{l}\text { Pembelajaran daring tidak membuat saya } \\
\text { mengeluarkan dana lebih untuk membeli kuota internet }\end{array}$ & $59 \%$ & $41 \%$ \\
\hline 6 & Pembelajaran daring tidak menyita waktu saya & $73 \%$ & $27 \%$ \\
\hline 7 & $\begin{array}{l}\text { Pembelajaran daring tidak membuat aktivitas saya } \\
\text { terganggu }\end{array}$ & $84 \%$ & $16 \%$ \\
\hline 8 & $\begin{array}{l}\text { Pembelajaran daring tidak membuat anak saya sulit } \\
\text { memahami materi pelajaran }\end{array}$ & $65 \%$ & $35 \%$ \\
\hline 9 & $\begin{array}{l}\text { Pembelajaran daring tidak membuat anak saya cepat } \\
\text { bosan }\end{array}$ & $50 \%$ & $50 \%$ \\
\hline 10 & $\begin{array}{l}\text { Pembelajaran daring membuat anak saya semakin } \\
\text { semangat belajar }\end{array}$ & $51 \%$ & $49 \%$ \\
\hline & Rata-rata & $74,8 \%$ & $25,2 \%$ \\
\hline
\end{tabular}

Berdasarkan tabel di atas, respon orang tua terhadap pembelajaran daring pada masa pandemi Covid-19 menunjukan rata-rata 74,8\% dengan katagori positif. Pada pernyataan pertama memperoleh skor 100\%. Hal Ini menujukkan bahwa pembelajaran daring pada masa pandemi Covid-19 memang membuat orang tua memiliki banyak waktu bersama anak, mereka dapat mendampingi dan membimbing anak ketika belajar. Sucipto dan Raflis (2000) mendefinisikan bimbingan sebagai segala kegiatan yang dilakukan seseorang kepada orang lain dalam rangka memberi bantuan karena mengalami kesulitan, agar orang tersebut mampu mengatasi kesulitannya sendiri penuh dengan kesadaran. Oleh karena itu, orang tua harus dapat membimbing anak secara berkelanjutan, terlebih pada masa pandemi Covid-19 di mana anak dituntut untuk belajar dari rumah. Ketika di 
sekolah, anak mendapat bimbingan dari gurunya. Maka ketika di rumah, anak sudah seharusnya mendapatkan bimbingan dari orang tuanya.

Pernyataan kedua, mendapatkan skor sebesar 98\% dengan kategori sangat positif. Orang tua setuju bahwa pembelajaran daring pada masa pandemi Covid-19 dapat membuat mereka semakin kompak dengan anak. Kekompakan itu dapat diwujudkan melalui kegiatan belajar sambil bermain dengan anak. Dalam tugastugas yang diberikan guru, salah satunya ada yang meminta kerjasama antara orang tua dan anak untuk menyelesaikan tugas tersebut. Kekompakan menjadikan anak merasa lebih dekat dengan orang tuanya. Sebagaimana pendapat Hermawan (2011) yang menjelaskan bahwa menjaga kekompakan dengan anak dapat berpengaruh pada tumbuh kembang anak, anak tumbuh menjadi pribadi yang lebih baik dan dia tidak akan terpengaruh pada hal yang negatif.

Item pernyataan ketiga didapat prosentase sebesar $100 \%$. Hal ini menunjukan bahwa dengan pembelajaran daring, orang tua dapat lebih mengenal sikap dan karakter anak. Orang tua perlu mengenal sikap dan karakter anak, ini dilakukan agar orang tua dapat mengarahkan anak dan membimbing anak ke halhal yang positif. Orang tua memiliki peran penting dalam pendidikan karakter anak, karena orang tua adalah orang terdekat anak. Selain itu, orang tua merupakan lembaga pendidikan pertama bagi anak. Orang tua merupakan miniatur terkecil dari masyarakat yang berkewajiban mendidik anaknya menjadi masyarakat yang bermoral dan beretika (Kurniawan, 2015).

Pada pernyataan keempat mendapatkan prosentase sebesar $68 \%$ orang tua tidak merasa kerepotan, dan 32\% merasa kerepotan saat harus mengawasi dan mendampingi anaknya belajar dari rumah. Kondisi belajar dari rumah secara daring memang merupakan pekerjaan tambahan untuk orang tua, orang tua harus memastikan bahwa anak-anaknya benar-benar belajar. Orang tua harus menjadi guru dadakan, mereka harus mengarahkan anaknya jika tidak memahami materi pelajaran yang diterima.

Pernyataan kelima dengan prosentase 59\% orang tua tidak mengeluarkan dana lebih untuk membeli kuota internet, dan 31\% orang tua harus mengeluarkan dana lebih untuk membeli kuota internet. Kuota internet merupakan kebutuhan pokok yang harus disediakan saat melaksanakan pembelajaran daring. Dikutip dari Yanti dkk (2020) bahwa pembelajaran daring dalam pelaksanaanya menggunakan jaringan internet dengan memanfaatkan teknologi informasi. Oleh karena itu, sebagian orang tua merasa harus mengeluarkan biaya lebih untuk membeli kuota internet, sebab penggunaan data yang melebihi dari biasanya.

Item selanjutnya yaitu pernyataan keenam, mendapatkan prosentase $73 \%$ pembelajaran daring tidak menyita waktu mereka, dan 27\% memilih bahwa 
pembelajaran daring dapat menyita waktu mereka. Orang tua dengan segudang aktivitasnya harus meluangkan waktu untuk anaknya saat pembelajaran daring di rumah. Orang tua harus memotivasi anaknya agar tidak cepat bosan selama belajar dari rumah. Sebagian besar tidak merasa menyita waktu mereka, karena mereka merasa bahwa mendampingi anaknya belajar adalah sebuah keharusan sebagai orang tua.

Item pernyataan ketujuh mendapatkan prosentase positif seberasar 84\%, artinya bahwa pembelajaran daring tidak mengganggu aktivitas orang tua. Mereka tetap dapat beraktivitas sambil mengawasi atau mendampingi anaknya saat pembelajaran daring dilakukan.

Pernyataan kedelapan, mendapatkan prosentase $65 \%$ orang tua menganggap pembelajaran daring tidak membuat anaknya sulit memahami materi pelajaran, dan 35\% memilih bahwa pembelajaran daring membuat anaknya sulit memahami materi. Pembelajaran daring dilaksanakan sama seperti pembelajaran pada umumnya, hanya saja dilakukan secara online di rumah tidak ada tatap muka langsung. Menurut Ashari dalam (Dewi, 2020) banyak guru menerapkan pembelajaran daring dengan cara-cara yang beragam, ada yang menggunakan konsep ceramah online, ada yang tetap mengajar di kelas seperti biasa tetapi direkam dengan video yang selanjutnya dikirim ke whatsapp group siswa.

Pada pernyataan kesembilan, mendapatkan prosentase $50 \%$ orang tua berpendapat bahwa pembelajaran daring membuat anaknya cepat bosan, dan 50\% berpedapat bahwa pembelajaran daring tidak membuat anaknya cepat bosan. Pembelajaran daring bersifat fleksibel, bisa diakses kapan saja dan di mana saja, sehingga pembelajaran ini cukup menyenangkan. Sebagaimana pendapat Sobron (2019) yang menyatakan bahwa pembelajaran daring membuat siswa senang, mereka dapat menyimak melalui HP android, laptop atau komputer, tidak hanya menyimak buku saja. Pembelajaran daring memang bisa saja membuat anak cepat bosan, sebab mereka tidak bisa belajar bersama-sama dengan teman sebayanya dan tidak bisa bertatap muka langsung dengan gurunya. Menurut Aulia Luqman Aziz seorang Pakar Pendidikan Universitas Brawijaya dalam (Kasih, 2020) berpendapat bahwa pembelajaran yang baik adalah pembelajaran yang dilakukan dengan tatap muka langsung dengan guru dan teman-temannya. Dengan adanya interaksi ini, siswa akan memperoleh nilai tambah pada proses pendewasaan sosial, budaya, etika dan moral.

Pernyataan terakhir adalah pernyataan kesepuluh, mendapatkan prosentase $51 \%$ orang tua merespon bahwa pembelajaran daring membuat anaknya semakin semangat belajar, dan 49\% merespon bahwa pembelajaran daring tidak membuat anaknya semangat belajar. Pembelajaran daring dapat 
dijadikan sebagai variasi model pembelajaran, pembelajaran tidak melulu dilakukan secara tatap muka langsung. Sebagaimana pendapat Dewi (2020) yang mengatakan bahwa pembelajaran daring merupakan suatu inovasi dalam dunia pendidikan dalam menjawab tantangan ketersediaan variasi sumber belajar. Dengan pembelajaran daring, siswa dapat berinteraksi dengan guru melalui berbagai aplikasi seperti whatsapp group, edmodo, zoom, google meet, dan google classroom.

\section{Simpulan}

Berdasarkan hasil penelitian tersebut, rata-rata prosentase respon orang tua yang didapat adalah positif. Jadi, dapat disimpulkan bahwa orang tua merespon positif terhadap pembelajaran daring pada masa pandemi Covid-19 ini, walaupun pembelajaran daring merupakan model pembelajaran baru yang diterapkan di KB-RA Mambaul Ulum. Pembelajaran daring membuat mereka banyak menghabiskan waktu bersama anak, sehingga menjadi lebih dekat dan mengenal karakter anak. Selain itu, pembelajaran daring juga membuat orang tua dan anak semakin kompak.

\section{Daftar Rujukan}

Dewi, Wahyu. A.F. (2020). Dampak Covid-19 terhadap Implementasi Pembelajaran Daring di Sekolah Dasar. Edukatif: Jurnal Ilmu Pendidikan, 2 (1), 55-61. https://edukatif.org/index.php/edukatif/article/view/89/pdf.

Kasih, A.P. (2020). Belajar dari Covid-19, Pakar UB: Peran Guru tidak Terganti Teknologi.https://edukasi.kompas.com/read/2020/05/04/140605771/b elajar-dari-covid-19-pakar-ub-peran-guru-tidak-tergantiteknologi?page=all.

Kuniawan, Machful Indra. (2015). Tri Pusat Pendidikan sebagai Sarana Pendidikan Karakter Anak Sekolah Dasar. Pedagogia: Jurnal Pendidikan, 4 (1), 41-49. http://ojs.umsida.ac.id/index.php/pedagogia/article/view/71.

Mustofa, MI, dkk. (2019). Formulasi Model Perkuliahan Daring Sebagai Upaya Menekan Disparitas Kualitas Perguruan Tinggi. WJIT: Walisongo Journal of Information Technology, 12 (2), 151-160. https://journal.walisongo.ac.id/index.php/jit/article/view/4067.

Sobron, A.N, dkk. (2019). Persepsi Siswa dalam Studi Pengaruh Daring Learning terhadap Minat Belajar IPA. Scaffolding: Jurnal Pendidikan Islam dan $\begin{array}{llll}\text { Multikulturalisme, } & 1 & \text { (2), }\end{array}$ https://ejournal.insuriponorogo.ac.id/index.php/scaffolding/article/view $\angle 117$.

Sudjana, Nana. (2001). Penelitian dan Penilaian Pendidikan. Bandung: Sinar Baru. Sucipto dan Raflis. (2000). Profesi Keorangtuaan. Jakarta: Rineka Cipta. 
Yanti, M.T, dkk. (2020). Pemanfaatan Portal Rumah Belajar Kemendikbud sebagai Model Pembelajaran Daring di Sekolah Dasar. Adi Widya: Jurnal Pendidikan Dasar, $\quad 5 \quad$ (1), 61-68. http://ejournal.ihdn.ac.id/index.php/AW/article/view/1306/1057. 